Z. klin. Chem. u. klin. Biochem.

9. Jg., S. $516-519$, November 1971

\title{
Assay of Triglycerides Using the Perkin Elmer C-4 Automatic Analyzer
}

By R. J. M. van Oers, R. J. H. Scholtis, N. A. Schmidt, J. F. van de Calseyde and A. M. J. Kuxpers

Department of Clinical Chemistry, Ignatius Hospital, Breda, The Netherlands. I

(Eingegangen am 7. Juni 1971)

EgGSTEIN's method for the enzymatic assay of triglycerides was adapted to the Perkin Elmer C-4 Automatic Analyzer and the repeatability, recovery, linearity and drift within a series were checked. The assay of triglycerides with the Perkin Elmer C-4 Automatic Analyzer was found to be highly reliable and rapid. With a few exceptions, it was found to be not necessary to estimate the free glycerol in addition to the total glycerol, which considerably reduces the length of this procedure.

Die Methode von Eggstern zur enzymatischen Bestimmung von Triglyceriden wurde an den automatischen Analysator Perkin Elmer C-4 angepaßt. Wiederholbarkeit, Wiederfindung, Linearität und Drift innerhalb der Serie wurden untersucht. Die Bestimmung der Triglyceride mit diesem Gerät ist sehr zuverlässig und schnell. Abgesehen von einigen Ausnahmen ist die Bestimmung des freien Glycerins neben dem Gesamtglycerin nicht erforderlich, wodurch der Zeitaufwand wesentlich verringert wird.

The demand for the automation of triglyceride assays is increasing with the demand for this procedure. So far only a semi-automated assay on a manually prepared isopropanol extract of the serum, based on the oxidation of glycerol to formaldehyde and the formation of a fluorescent product, has been described (1). The present authors believe that the Perkin Elmer C-4 Automatic Analyzer provides a suitable instrument for the enzymatic assay of triglycerides by EGGSTEIN's method $(2,3,4)$.

This enzymatic assay was adjusted to the Perkin Elmer C-4 Automatic Analyzer, and the repeatability, recovery, linearity and drift within a series were checked.

In order to determine whether the concentration of free glycerol should also be estimated in routine triglyceride assays, the free glycerol concentrations found in well over 1,000 assays were compared with the total glycerol concentrations.

The Perkin Elmer C-4 Automatic Analyzer (Fig. 1) is a discrete sampling automatic analyzer by which up to four different assays may be carried out at the same time. The rate of the apparatus is $120,60,40$ or 30

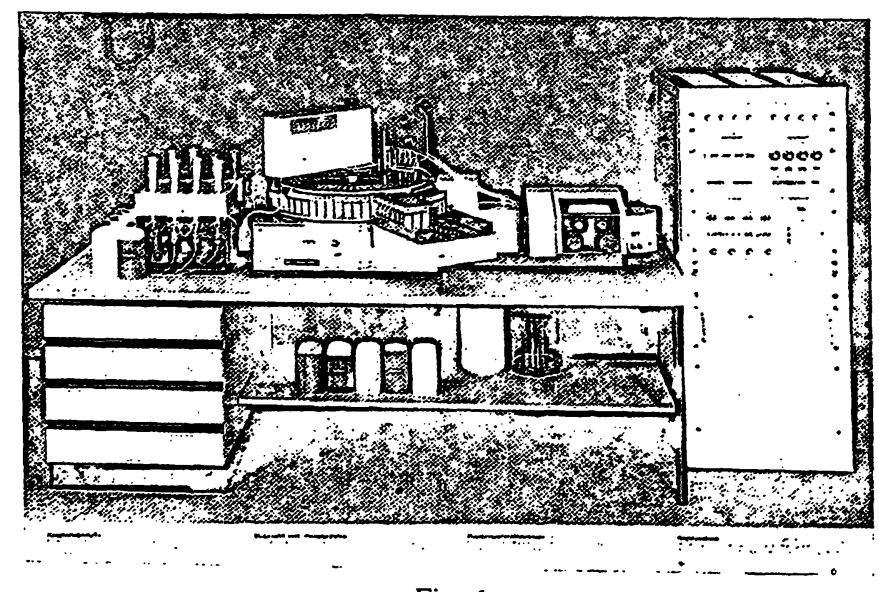

Fig.

Perkin Elmer C-4 Automatic Analyzer

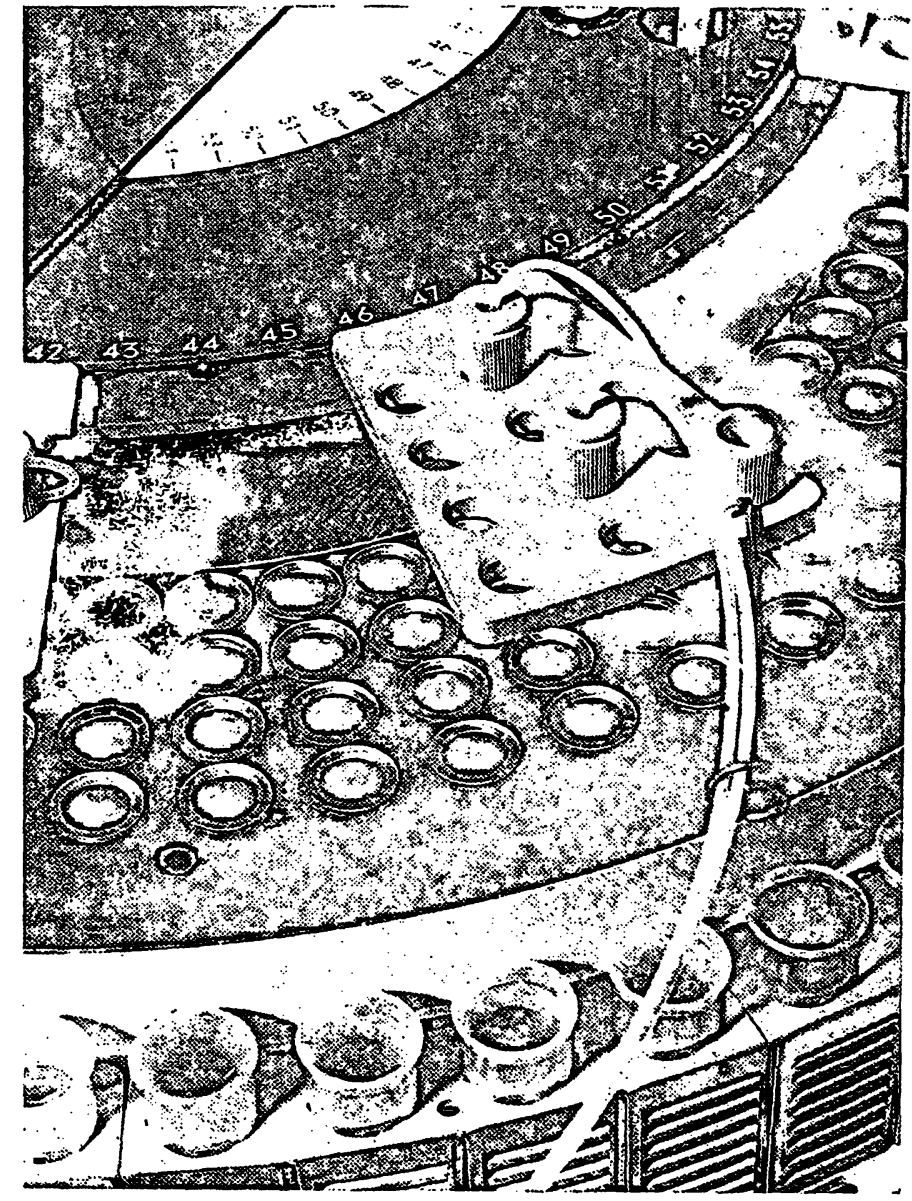

Fig. 2

Rotary table with two reagent additions in channel II and channel IV. Sample cups are visible in the outer channel

samples per hour, varying with the number of assay channels $(1,2,3$ or 4 channels respectively).

The Perkin Elmer C-4 consists of a sampling pump which may be adjusted from 0 to $940 \mu \mathrm{l}$, a rotary table in which there are concentric circles (4 channels) (Fig. 2) each of which contains 60 reaction vessels thermostated by a water bath adjustable from 15 to 


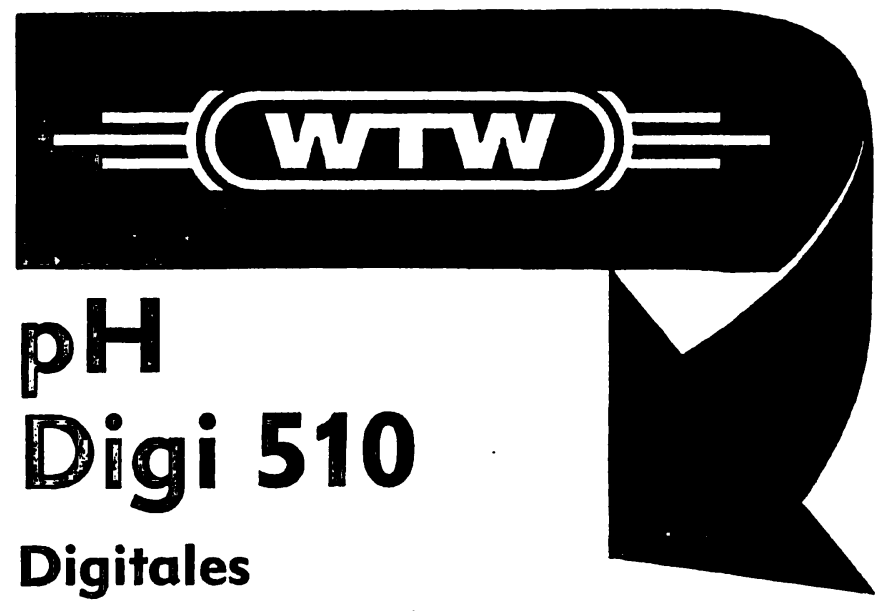

Präzisions-pH/mV-Meter

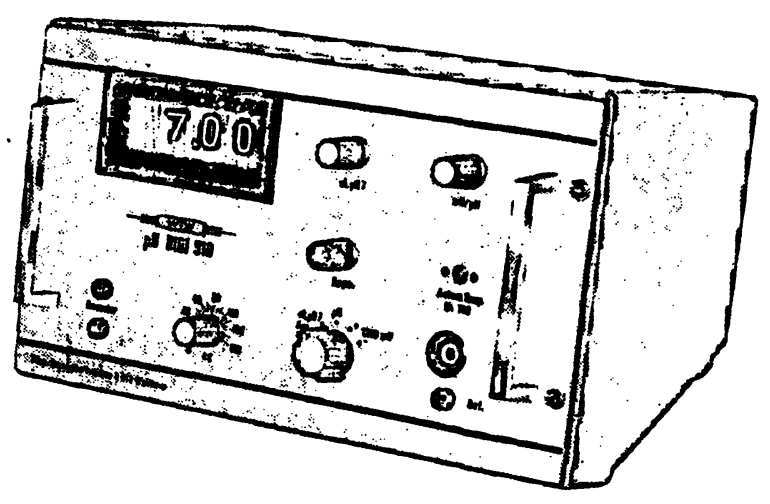

- Bereich pH 0,00 - 14,00/ $\pm 1999 \mathrm{mV}$

- Genauigkeit $\pm 0,01 \mathrm{pH} / \pm 1 \mathrm{mV}$

Temperaturkompensation wahlweise manuell oder automatisch, Potentialmessung mit allen Elektrodensystemen incl. ionensensitiv

- Wertangabe direkt als Zahl

- irrtumsfreie Ablesung

- rationelles Arbeiten

- angemessener Preis

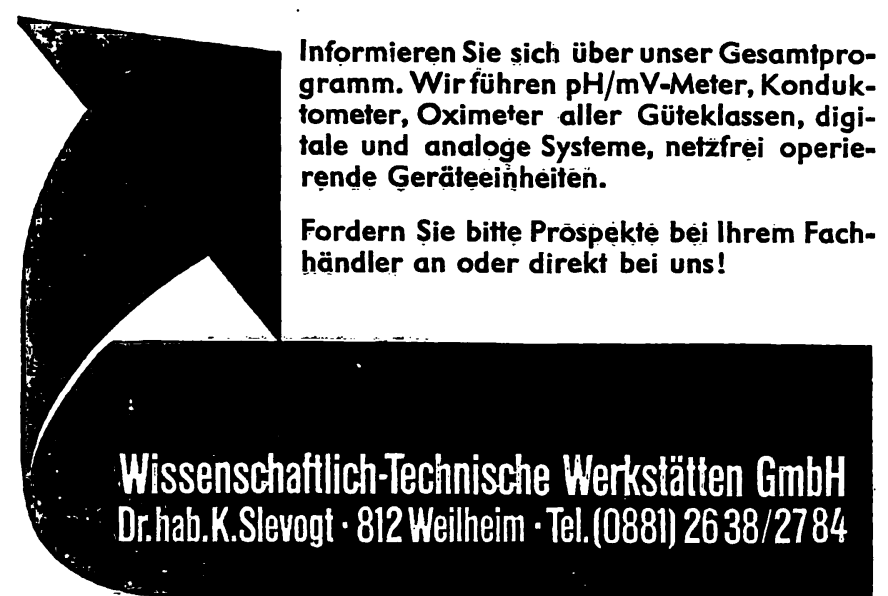

Büros: 4300 Essen K.Akemann, Lönsberg 22, Tel. (02141) 5100.19 7407 Dusslingen bei Tübingen W. Bohñ, Farrenbergweg 5 , Tel. (07128) 7809

5800 Hagen H. Duckstein, HestertstraBe 64, Tel. (02331) 45857

6350 Bad Nauheim H. Ballauff, Frankfurter Stri. 39, Tel. (0603z) 4860

Labo-Nr.

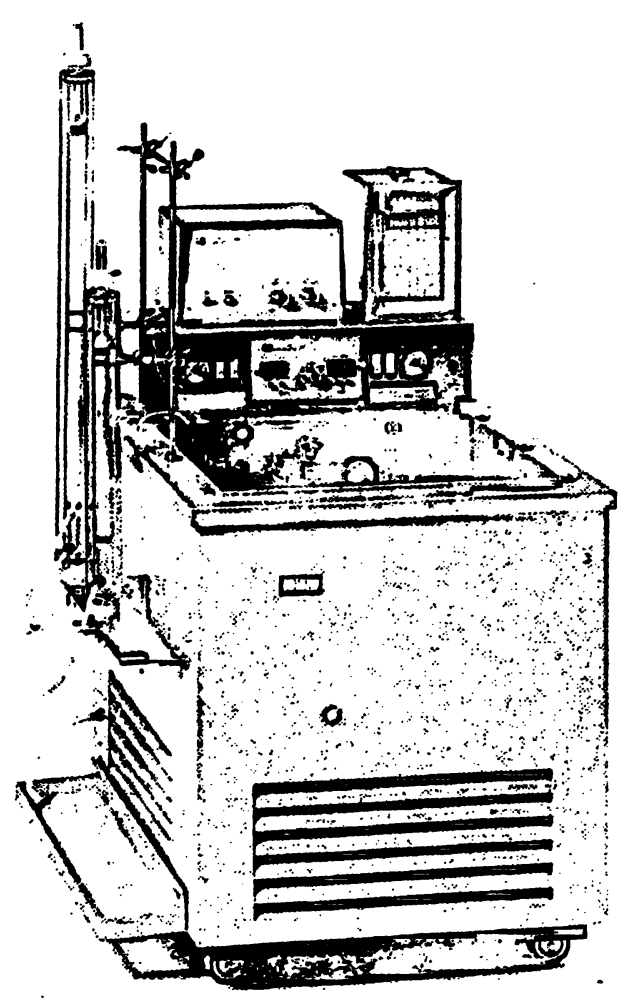

\section{Colora-Kühlgerät für die Chromatographie}

Das wegen seiner Zuverlässigkeit' auf dem Weltmarkt führende Gerät ermöglicht automatische Kühlung der Trennsäulen und Fraktionen. Große Kühltruhe zur Aufnahme von LKBFraktionensammler UltroRac, Durchflußanalysator Uvicord, Pumpe und Zubehör. Getrennte Kühlsysteme fürTrennsäulen und Truhe. Temperaturkonstanz $\pm 1^{\circ} \mathrm{C}$ in Kühlraum und Kühlsole, in den Säulen $\pm 0,2^{\circ} \mathrm{C}$.

\section{Colora Messtechnik GmbH}

\section{Lorch/Württ., Postfach 5} T (07172) 6041, FS 07-248 886

Technische Büros (Verkauf und Kundendienst): 1000 Berlin 30, Kurfürstenstraße 84, T 2615200 2000 Hamburg 19, Osterstraße 63, T 491 10 34, FS 02-12 947 3000 Hannover, An der Tiefenriede 45, T 884500 4000 Düsseldorf, Kronprinzenstr. 62, T 320164 , FS 08-587 253 6000 Frankfurt a.M., Röderbergweg 4-6,T446031, FS 04-11 216 8000 München 19, Dachauer Straße 175, T 193858

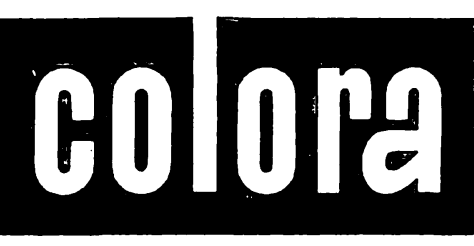




\title{
BIOCHIMIE
}

\section{Edité par la Société de Chimie Biologique}

\author{
tel est le titre \\ sous lequel paraîtra à partir de 1971 \\ le „BULLETIN DE LA SOCIÉTÉ DE CHIMIE BIOLOGIQUE“ ,
}

\section{SECRÉTARIAT}

de la Société de Chimie Biologique

J. P. EBEL, Secrétaire Général (Relations Extérieures)

R. PERLES, Secrétaire Général

\section{REDACTION}

F. GROS, Secrétaire scientifique

F. PERCHERON, Secrétaire à la Publication J. NUNEZ, Secrétaire à l'Information

Y. RAOUL, Secrétaire à l'Edition

SECRETARIAT et REDACTION: 4 Avenue de l'Observatoire, PARIS $6^{\circ}$

12 FASCICULES

ABONNEMENTS: FRANCE et ZONE FRANC: $150 \mathrm{ffrcs}$ - BELGIQUE: $1.687,-$ frcs - AUTRES PAYS: $186,-\mathrm{ffrcs}$

MASSON et Cie, Editeurs - 120 Boulevard St Germain - PARIS 6ème

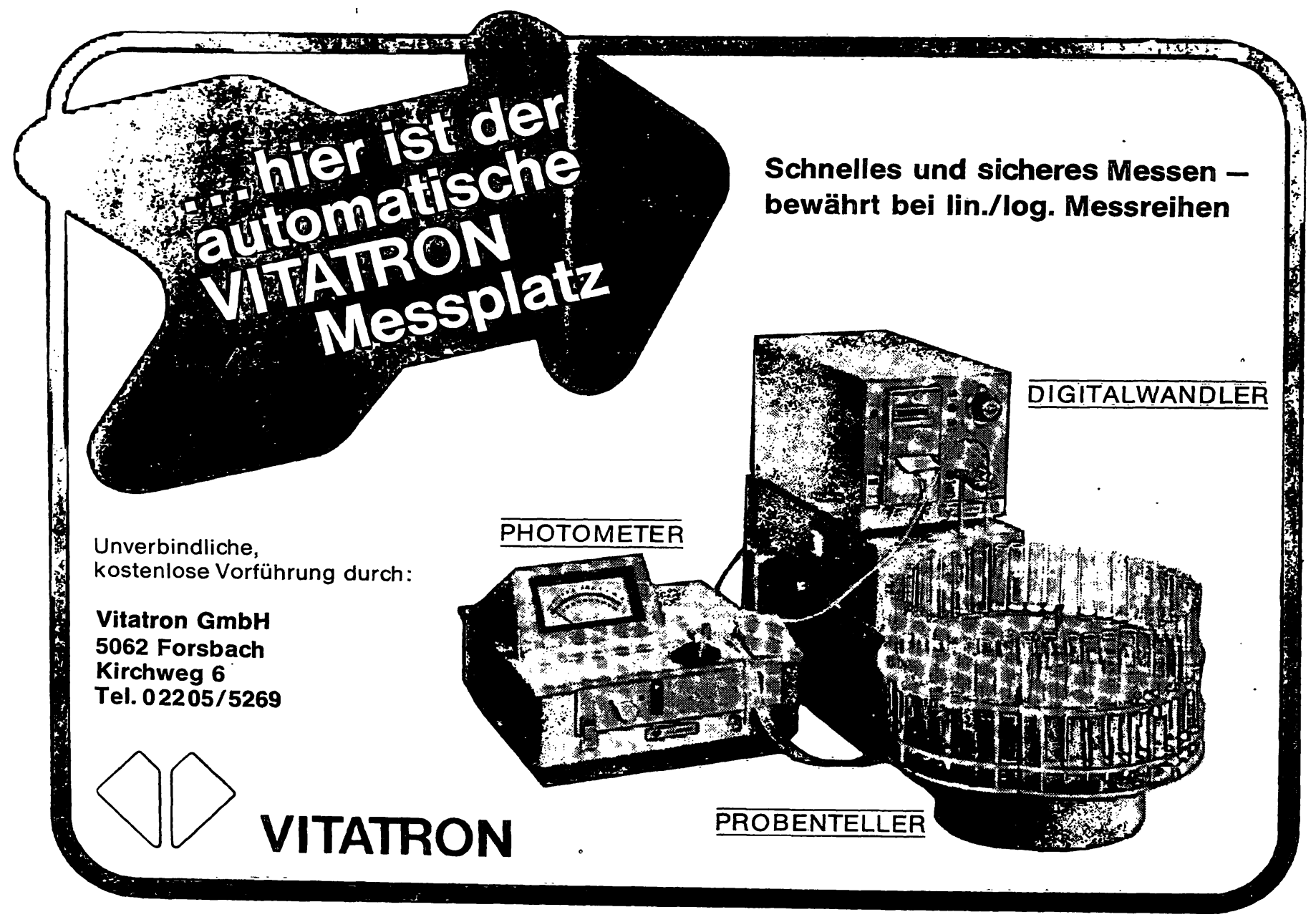


$60^{\circ}$, reagent pumps, each adjustable from 50 to $2500 \mu \mathrm{l}$, and a spectrophotometer which automatically controls the one hundred per cent balance for four channels by the width of the slit. The extinctions are automatically converted into concentration units. The results are printed. In addition, the signals emitted by the spectrophotometer may be recorded on a recorder. The times at which sampling is done and at which various reagents are added, are adjustable with regard to the measuring period.

\section{Material and Methods}

\section{Principle of the reaction}

Glycerol is enzymatically estimated in serum before (free glycerol) and after (total glycerol) alkaline saponification. The amount of $\mathrm{NADH}$ utilized, which is determined at $340 \mathrm{~nm}$, is a measure of the amount of glycerol.

$$
\begin{aligned}
& \text { Glycerol }+\mathrm{ATP} \stackrel{\mathrm{a}}{\rightarrow} \text { Glycerol-1-P }+\mathrm{ADP} \\
& \text { Phosphoenolpyruvate }+\mathrm{ADP} \stackrel{\mathrm{b}}{\longrightarrow} \text { Pyruvate }+\mathrm{ATP} \\
& \text { Pyruvate }+\mathrm{NADH}+\mathrm{H}^{+} \stackrel{\mathrm{c}}{\longrightarrow} \text { Lactate }+\mathrm{NAD} \\
& \text { a. Glycerokinase } \\
& \text { b. Pyruvate kinase } \\
& \text { c. Lactate dehydrogenase. }
\end{aligned}
$$

\section{Reagents}

Ethanolic potassium bydroxide $0.5 \mathrm{~N}$ : Dissolve $3.3 \mathrm{~g}$ of potassium hydroxide (Merck $5033, \approx 86 \% \mathrm{KOH}$ ) in $10 \mathrm{ml}$ of twice distilled water, allow to cool and make up to $100 \mathrm{ml}$ with 96 per cent ethanol.

This remains stable for one month at approximately $4^{\circ}$.

Magnesium sulphate: Dissolve $37 \mathrm{~g}$ of $\mathrm{MgSO}_{4}-7$ aq. (Merck 5886) and make up to $1,000 \mathrm{ml}$ with distilled water.

0.9 Per cent sodium chloride: Dissolve $9 \mathrm{~g}$ of $\mathrm{NaCl}$ (Merck 6404) in one litre of distilled water.

Trietbanolamine buffer $0.1 \mathrm{M}, p H$ 7.6: Dissolve $14 \mathrm{~g}$ of triethanolamine (Merck 8379 ) and $1 \mathrm{~g}$. of $\mathrm{MgSO}_{4}-7 \mathrm{aq}$. in $900 \mathrm{ml}$ of distilled water. Adjust to $\mathrm{pH} 7.6$ with $\mathrm{HCl} 6 \mathrm{~N}$ and make up to $1,000 \mathrm{ml}$ with distilled water.

$N A D H$-Phosphoenolpyruvate- $A T P$ solution: Make up $20 \mathrm{mg}$ of $\mathrm{NADH}$ di-sodium salt (Boehringer $15142 \mathrm{CNAB}$ ) $120 \mathrm{mg}$ of ATP di-sodium salt (Boehringer $15028 \mathrm{NAAH}$ ) and $14 \mathrm{mg}$ of phosphoenolpyruvate-mono-potassium salt (Boehringer 15179 $\mathrm{SPAB}$ ) to $120 \mathrm{ml}$ with triethanolamine buffer.

Prepare fresh solution in each case.

The concentration of NADH has been chosen in such a way that the reaction will be linear up to $6.0 \mathrm{~mm}$.

Lactate dehydrogenase-Pyruvatekinase solution: Make up $1 \mathrm{ml}$ of lactate dehydrogenase suspension ( $10 \mathrm{mg} / 2 \mathrm{ml}$, Boehringer $15371 \mathrm{ELAC})$ and $0.25 \mathrm{ml}$ of pyruvate kinase suspension $(10 \mathrm{mg} / \mathrm{ml}$, Boehringer 15744 EPAU) to $50 \mathrm{ml}$ with triethanolanine buffer, $\mathrm{pH}$ 7.6.

Prepare fresh solution in each case.

Glycerokinase solution: Màke up $0.25 \mathrm{ml}$ of glycerokinase suspension ( $5 \mathrm{mg} / \mathrm{ml}$, Boehringer $15746 \mathrm{EGAP}$ ) to $25 \mathrm{ml}$ with triethanolamine buffer, $\mathrm{pH}$ 7.6.

Prepare fresh solution in each case.

Glycerol standard: Accurately weigh out approximately $1,000 \mathrm{mg}$ of glycerol (Merck 4094) and make up to $1,000 \mathrm{ml}$ with glycerol free water.

This remains stable for approximately two months at about $4^{\circ}$. Make up $5 \mathrm{ml}$ of this solution to $100 \mathrm{ml}$ with distilled water.

Molarity of this standard solution $=$ weight $(\mathrm{mg}) \cdot \frac{87}{92} \cdot \frac{1}{2000}=\mathrm{mm}$.
Triolein standard: Transfer contents of a triolein ampoule (Sigma $\mathrm{T}-7502)$ to $50 \mathrm{ml}$ volumetric flask with a small quantity of ether. Make up to $50 \mathrm{ml}$ with 96 per cent ethanol. Molarity of this standard solution $\approx 2 \mathrm{~mm}$.

\section{Method of estimation}

When EgGstern's enzyme triglyceride assay (2) is used, the sample to be analysed is added to a triethanolamine buffer, $\mathrm{pH} 7.6$, containing ATP, phosphoenolpyruvate, pyruvate kinase, NADH and lactate dehydrogenase. The extinction is monitored for 5-10 minutes (Fig. 3). Glycerokinase having been added, extinction is followed again for 5-10 minutes.

The difference in extinction before and after addition of the glycerokinase solution, extrapolated to the time at which glycerokinase is added, provides a measure of the amount of glycerol in the sample to be analysed.

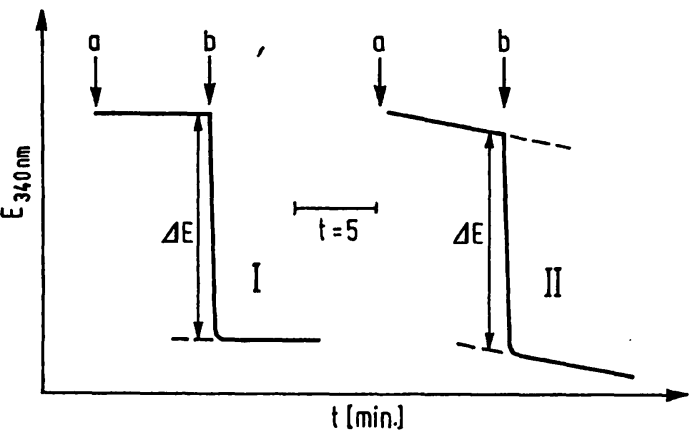

Fig. 3

Determination of glycerol. Extinction before and after addition of glycerokinase

I. total glycerol II. free glycerol

a) addition of sample b) addition of glycerokinase - non-specific reactions

Enzyme assays of the free glycerol in the serum are accompanied by non-specific reactions (Fig. 3), resulting in reduced extinction. These non-specific reactions do not occur when glycerol is assayed in saponified samples, which have been correctly neutralized. The following method was adopted by the present authors in performing this assay with the Perkin Elmer C-4 (Fig. 4).

With the exception of glycerokinase, the reagents and the sample are introduced into both channel I and channel II. Within ten minutes after adding the sample, the glycerokinase solution is introduced into channel I and an equal volume of triethanolamine buffer is introduced into channel II. The actual reaction therefore occurs in channel $\mathrm{I}$, whereas changes in extinction resulting from dilution and nonspecific reactions, if any, can only occur in channel II. Within eleven minutes after glycerokinase has been added to channel $\mathrm{I}$, the extinction of channel $\mathrm{I}$ is determined in comparison

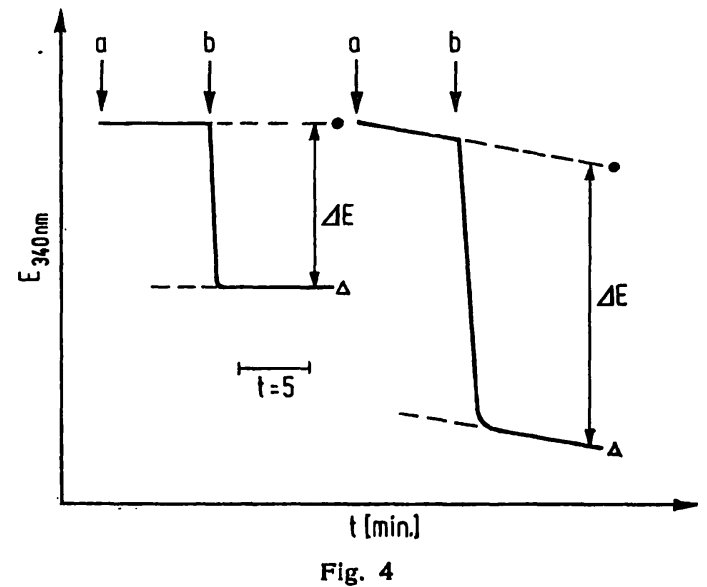

Determination of glycerol by comparison of the extinction of channel 1 $\Delta$ ) with that of channel II (•)

a) addition of sample b) addition of glycerokinase to channel I 
with that of channel II (Fig. 4), which corresponds with $\triangle \mathrm{E}$ of Figure 3 as the extinctions in channels $I$ and II run parallel to one another following the addition of glycerokinase. This assay using the Perkin Elmer C-4, accordingly requires two channels, resulting in a maximum number of 60 samples per hour.

\section{Adjustment of Perkin Elmer C-4}

Channel selector: $1+2 ; 25^{\circ} ; 5$ Reagent pumps sampling pump, total quantity of sample $400 \mu 1$

\begin{tabular}{|c|c|c|c|c|}
\hline Channel & 1 & II & III & IV \\
\hline $\begin{array}{l}\text { Wave-length, } \mathrm{nm} \\
\text { Sample volume, } \mu \mathrm{l}\end{array}$ & $\begin{array}{l}340 \\
200\end{array}$ & $\begin{array}{l}340 \\
200\end{array}$ & 二 & $=$ \\
\hline $\begin{array}{l}\text { 1. NADH - phosphoenolpyru- } \\
\text { vate - ATP } \mu l\end{array}$ & 1,000 & 1,000 & - & - \\
\hline $\begin{array}{l}\text { 2. Lactate dehydrogenase - } \\
\text { pyruvate kinase } \mu \mathrm{l}\end{array}$ & - 200 & 200 & - & - \\
\hline $\begin{array}{l}\text { 3. Glycerokinase } \mu 1 \\
\text { 4. Triethanolamine Buffer } \mu 1\end{array}$ & 200 & 200 & 二 & 二 \\
\hline 5. Triethanolamine Buffer $\mu 1$ & 1,000 & 1,000 & & \\
\hline
\end{tabular}

\section{Method of saponification}

The following materials are pipetted into a centrifuge tube:

$$
\begin{aligned}
& \text { ethanolic } \mathrm{KOH} 0.5 \mathrm{~N} 0.5 \mathrm{ml} \\
& \text { serum } \quad 0.2 \mathrm{ml} \text {. }
\end{aligned}
$$

The tubes are well sealed and saponified for thirty minutes at $70^{\circ}$ After cooling, the following solution is added:

$$
\mathrm{MgSO}_{4} \text { solution } 0.15 \mathrm{M} 1.0 \mathrm{ml}
$$

This is well mixed and then centrifuged again for five minutes at 3,000 r.p.m. The supernatant fluid is stored at $4^{\circ}$. In lieu of serum, $0.2 \mathrm{ml}$ of 0.9 per cent $\mathrm{NaCl}$ should be used as a saponification blank in the above saponifying procedure. $0.2 \mathrm{ml}$ of the triolein standard are also saponified and estimated.

$$
\begin{array}{ll}
\text { Saponified sample factor: } & 17.7 \\
\text { Free glycerol factor: } & 2.08
\end{array}
$$

Saponified sample factor $=\frac{2.6 \cdot 8.5}{6.23 \cdot 0.2}$ and free glycerol factor $=$

$$
\frac{2.6}{6.23 \cdot 0.2}
$$

in which 2.6: total volume

8.5: dilution factor of saponified sample

$6.23 \cdot 10^{3}$ : millimolar coefficient of extinction of $\mathrm{NADH}$ at $340 \mathrm{~nm}$

0.2 : volume of sample.

As shown in Figure 5 , solutions 1 and 2 are initially transferred to the reaction vessel, followed by the sample. This will start the secondary reaction. Ten minutes later, the glycerokinase solution is introduced into channel $I$, triethanolamine buffer being introduced into channel II in lieu of this solution.

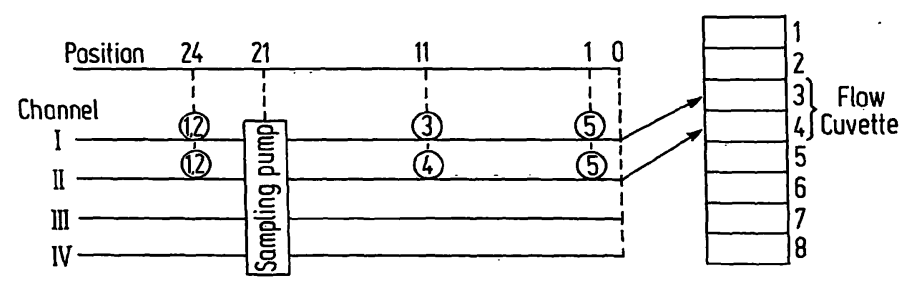

Fig. 5

Adjustment of the Perkin Elmer C-4 Automatic Analyzer
In order to bring the extinction within a measurable range, triethanolamine buffer is introduced into the two channels at position 1 . The reaction will therefore occur in channel I. Within eleven minutes after the glycerokinase solution has been added, the Perkin Elmer C-4 transfers the contents of channel I to flow cuvette 3 and that of channel $I I$ to flow cuvette 4 . The transmission of cuvette 3 is automatically adjusted to one hundred per cent by the width of the slit, and cuvette 4 is measured against cuvette 3 .

\section{Results}

Table 1 shows the ratio of free glycerol to total glycerol in over 1,000 serum samples, each in mMoles per litre. Of the free glycerol, the average, standard deviation and number of free glycerol assays in each area are stated.

It is apparent from Table 1 that when the total glycerol increases to $6.0 \mathrm{~mm}$, the free glycerol will only increase by a minute amount to approximately $0.16 \mathrm{~mm}$. Whien the normal total glycerol levels of the 1,000 assays are estimated by the methods as suggested by Neuman (5) and HoFFMAN (6), these levels are found to vary from 0.6 to $2.2 \mathrm{~mm}$.

When routine triglyceride assays are carried out, it is not necessary to estimate the concentrations of free glycerol. If the lipid pattern is found to be normal when the concentration of triglycerides shows an increase (in which case the lipid pattern is invariably determined), the free glycerol concentration of the sample may still be determined so that the triglyceride level can be adjusted.

\section{Repeatability}

Duplicate determinations are made of the total glycerol concentration, i. e. the serum sample is saponified and assayed on two consecutive days.

Table 2 provides an example of a series of duplicate determinations.

Tab. 2

Results of duplicate (triplicate) triglyceride assays (mMoles/1 glycerol) in brackets: outliers

\begin{tabular}{ccccc|cc|ccc|cc}
\hline \multicolumn{10}{c}{ Day: } \\
1 & 2 & 3 & 1 & 2 & 1 & 2 & 1 & 2 & 3 & 1 & 2 \\
\hline 1.1 & 1.3 & & 3.1 & 3.1 & 3.0 & 2.9 & 1.4 & 1.3 & & 0,9 & 0.9 \\
1.4 & 1.5 & & 1.8 & 1.8 & 1.0 & 1.1 & $(0.5)$ & 1.9 & 2.0 & 2.5 & 2.4 \\
1.5 & 1.6 & & 1.6 & 1.5 & 1.2 & 1.3 & 0.8 & 0.9 & & 1.6 & 1.5 \\
0.7 & 0.7 & & 1.8 & 1.7 & 1.0 & 1.1 & 0.8 & 0.9 & & 1.9 & 1.7 \\
0.9 & 1.0 & & 0.5 & 0.6 & 1.6 & 1.6 & 3.6 & 4.1 & & 1.4 & 1.3 \\
$(3.3)$ & 2.3 & 2.2 & 2.4 & 2.5 & 1.3 & 1.3 & 4.5 & 4.9 & & 1.3 & 1.2 \\
1.2 & 1.3 & & 2.0 & 2.0 & 2.3 & 2.3 & $(4.4)$ & 1.8 & 1.6 & 2.0 & 2.0 \\
0.9 & 0.9 & & 2.1 & 2.2 & 4.6 & 4.7 & 1.9 & 1.9 & & 1.2 & 1.2 \\
1.5 & 1.6 & & 1.7 & 1.8 & 2.1 & 3.0 & 3.2 & 3.4 & & 3.1 & 3.2 \\
3.5 & 3.3 & & 1.7 & 1.8 & 1.5 & 1.5 & 0.7 & 1.0 & & 2.1 & 1.9 \\
\hline
\end{tabular}

The above table shows that, with a few exceptions, the

\begin{tabular}{|c|c|c|c|c|c|c|c|c|c|c|c|c|}
\hline $\begin{array}{l}\text { Total glycerol } \\
\text { Free glycerol } \bar{x} \\
\text { S. D. } \\
\text { Number of probands }\end{array}$ & $\begin{array}{l}0.0-0.5 \\
0.07 \\
0.06 \\
21\end{array}$ & $\begin{array}{l}0.5-1.0 \\
0.07 \\
0.05 \\
209\end{array}$ & $\begin{array}{l}1.0-1.5 \\
0.09 \\
0.06 \\
273\end{array}$ & $\begin{array}{l}1.5-2.0 \\
0.10 \\
0.06 \\
231\end{array}$ & $\begin{array}{l}2.0-2.5 \\
0.11 \\
0.08 \\
115\end{array}$ & $\begin{array}{l}2.5-3.0 \\
0.12 \\
0.08 \\
63\end{array}$ & $\begin{array}{l}3.0-3.5 \\
0.14 \\
0.09 \\
34\end{array}$ & $\begin{array}{l}3.5-4.0 \\
0.13 \\
0.09 \\
27\end{array}$ & $\begin{array}{l}4.0-4.5 \\
0.15 \\
0.12 \\
15\end{array}$ & $\begin{array}{l}4.5 \div 5.0 \\
0.16 \\
0.15 \\
13\end{array}$ & $\begin{array}{l}5.0-5.5 \\
0.13 \\
0.08 \\
6\end{array}$ & $\begin{array}{l}5.5-6.0 \\
0.13 \\
0.17 \\
8\end{array}$ \\
\hline
\end{tabular}
maximum difference between two duplicate levels is $0.2 \mathrm{mMoles}$ per litre. Glycerol assays using the Perkin Elmer C-4 are readily repeatable but duplicate estima-

Tab. 1

Comparison of free glycerol and total glycerol (mMoles/l) 


\section{Auch die kleinste Bestellung wird von uns wie ein großer Auftrag behandelt.}

Eine Ratte - drei Tage schwanger.

Eine männliche Maus - 18-20 gr. schwer. Oder irgendeine Maus oder Ratte nach Ihren speziellen Wünschen.

Wir sind für jede Bestellung dankbar, egal ob sie groß oder klein ist. Dafür liefern wir Ihnen die besten Versuchstiere, die Sie kaufen können. Diese Tiere werden unter denselben gewissenhaften Bedingungen gezüchtet, die von den Charles River Laboratorien in ganz Nord-Amerika gestellt werden.

Da dies die besten und gesündesten Tiere sind, die zur Verfügung stehen, benötigen sie keine besonderen Behausungen, um einheitlichere Forschungsergebnisse zu erzielen. Das bedeutet, dass die Auswertung der wissenschaftlichen Fakten äuBerst präzise ist. Was wollen Sie mehr?

Die Arche Noah nahm immer nur zwei Tiere auf. Wir verschicken unsere Versuchstiere auch einzeln - oder soviele wie Sie wollen. Ein Anruf genügt:

(35) 771887.

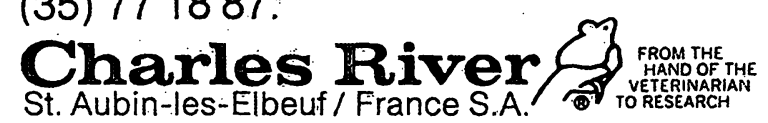




\section{Über Platin- *Blockelektroden für die Hoch- und Niederspannungs- Elektrophorese weiß man leider viel zu wenig !}

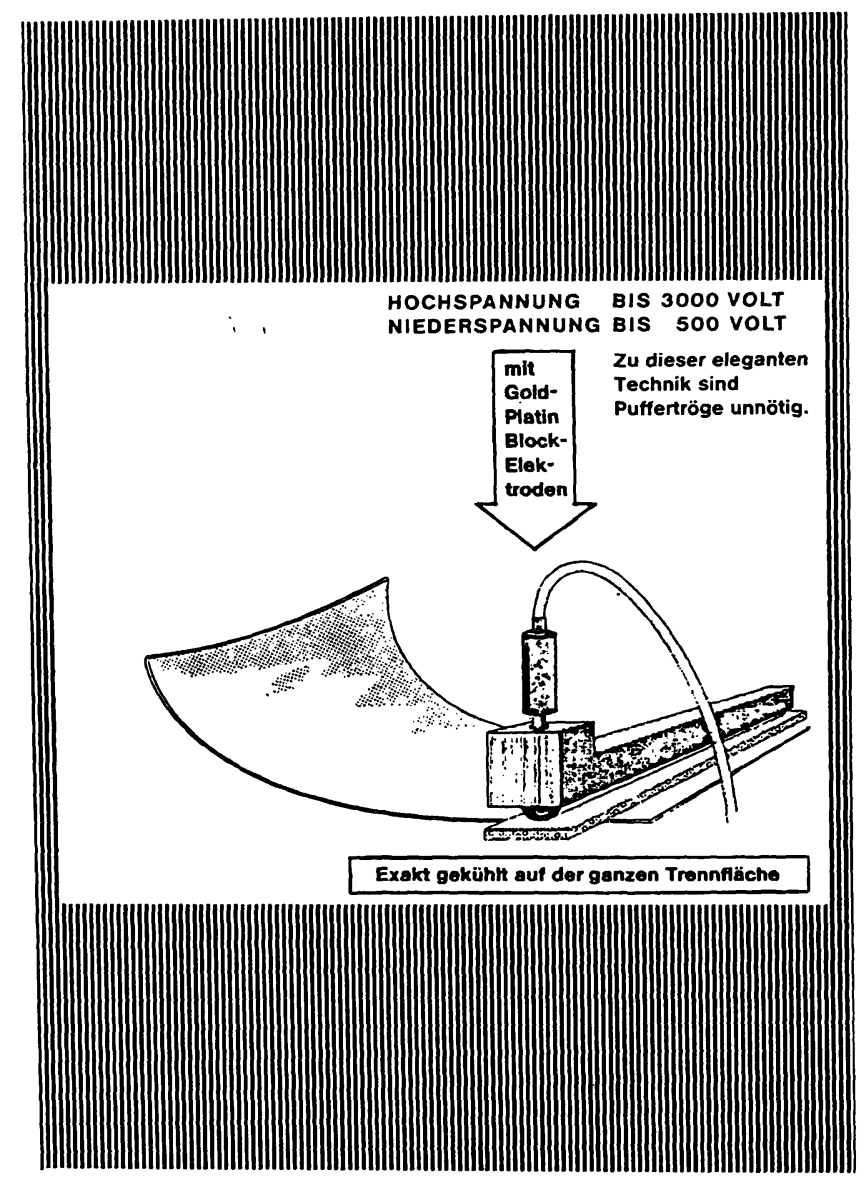

* z. B. für den Pherograph Mini 68

Unsere interessante Druckschrift HNE 5-6913 informiert Sie ausführlich.

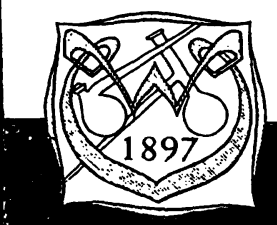

WISSENSCHAFTLICHE APPARATE HORMUTH-VETTER 6908 Wiesloch/Bd., Postfach 1348, Tel. 06222/21 47 6900 Heidelberg 1, Postfach 750, Tel. 0622120045

\section{Walter de Gruyter Berlin·New York}

\section{Neuerscheinung}

\section{G.L.Squires}

\section{Meßergebnisse und ihre Auswertung}

Eine Anleitung zum praktischen naturwissenschaftlichen Arbeiten

Von G. L. Squires, Physikdozent an der Cambridge University und Fellow of Trinity College. Groß-Oktav. 240 Seiten. Mit 77 Abbildungen und zablreichen Formeln und Tabellen. 1971. Plastik flexibel DM 29,- (de Gruyter Lehrbuch)

Dieses Buch demonstriert das sinnvolle und zielstrebige Vorgehen und das selbstkritische Überprüfen der Ergebnisse, die bei allen naturwissenschaftlichen und technischen Arbeiten angestrebt werden sollten. Es soll ein Begleitbuch für die Grundausbildung im Praktikum und eine Hilfe bei der Durchführung selbständiger experimenteller Untersuchungen und deren Veröffentlichung sein.

Die Wesenseinheit von Theorie und Experiment wird durch das Angeben expliziter Beispiele für die Wechselwirkung zwischen beiden betont. Wann immer ein neuer Gesichtspunkt im Text erwähnt wird, wird er sofort durch ein Beispiel veranschaulicht. Diese Beispiele sind so einfach gehalten, daß der Leser ihnen ohne Schwierigkeiten folgen kann. Viele Übungen an den . Enden der Kapitel sollen die einzelnen im Text exarbeiteten Ideen vertiefen und bilden damit einen integralen Bestandteil des Textes. Sie umfassen Diskussionsthemen und Rechenaufgaben. Lösungen für alle Rechenübungen sowie Hinweise auf den Lösungsweg - sofern erforderlich sind angegeben. 
Tab. 3

Stability of saponified samples of triglycerides (mMoles/l glycerol)

\begin{tabular}{cccccccc}
\hline Serum & & & & & & \\
\hline 1 & 0.7 & 1.0 & 0.7 & 0.7 & 0.8 & 0.7 \\
2 & 0.9 & 0.9 & 0.9 & 0.9 & 0.8 & 0.8 \\
3 & 1.9 & 2.1 & 2.1 & 2.2 & 2.0 & 2.1 \\
Saponified day & 1 & 2 & 3 & 3 & 3 & 3 \\
Assayed day & 2 & 3 & 4 & 5 & 6 & 9 \\
\hline
\end{tabular}

tions are essential because of the occasional outliers which are due to the saponification procedure.

Efforts were made to determine whether saponified samples would remain stable.

For this purpose, samples were saponified and assayed on different days. Table 3 shows that saponified samples stored at approximately $4^{\circ}$, continue to display a similar activity a few days later.

\section{Drift and recovery of the Perkin Elmer C-4}

In order to determine the drift within a series of assays as well as the recovery of the Perkin Elmer C-4, a glycerol standard was introduced whenever ten samples had been assayed, and estimated with an adjusted theoretical factor based on the millimolar coefficient of extinction of $\mathrm{NADH}$ at $340 \mathrm{~nm}$. Table 4 shows that a

Tab. 4

Drift and recovery of a glycerol standard within a series (mMoles/l)

\begin{tabular}{lll}
\hline $3.72=99 \%$ & $3.67=98 \%$ & $3.73=99 \%$ \\
$3.78=101 \%$ & $3.50=93 \%$ & $3.67=98 \%$ \\
$3.70=99 \%$ & $3.61=96 \%$ & $3.80=101 \%$ \\
$3.75=100 \%$ & $3.71=99 \%$ & $3.79=101 \%$ \\
$3.71=99 \%$ & $3.67=98 \%$ & $3.94=105 \%$ \\
$3.91=104 \%$ & $3.59=96 \%$ & $3.83=102 \%$ \\
$3.77=101 \%$ & $3.57=95 \%$ & $3.90=104 \%$ \\
1 st series & 2nd series & 3rd series \\
\hline
\end{tabular}

significant drift is absent in a series of assays of approximately seventy samples, and that recovery of the glycerol standard is almost one hundred per cent.

\section{Linearity of assays}

The area for which linearity holds good, will vary with the concentration of NADH. Estimates made at $340 \mathrm{~nm}$, are more sensitive than those made at $360 \mathrm{~nm}$. Thus if $340 \mathrm{~nm}$ is used the maximum amount of NADH which can be dissolved in solution 1 is $20 \mathrm{mg}$ per $120 \mathrm{ml}$, in order to make the automatic one hundred per cent adjustment of transmission by the width of the slit practicable.

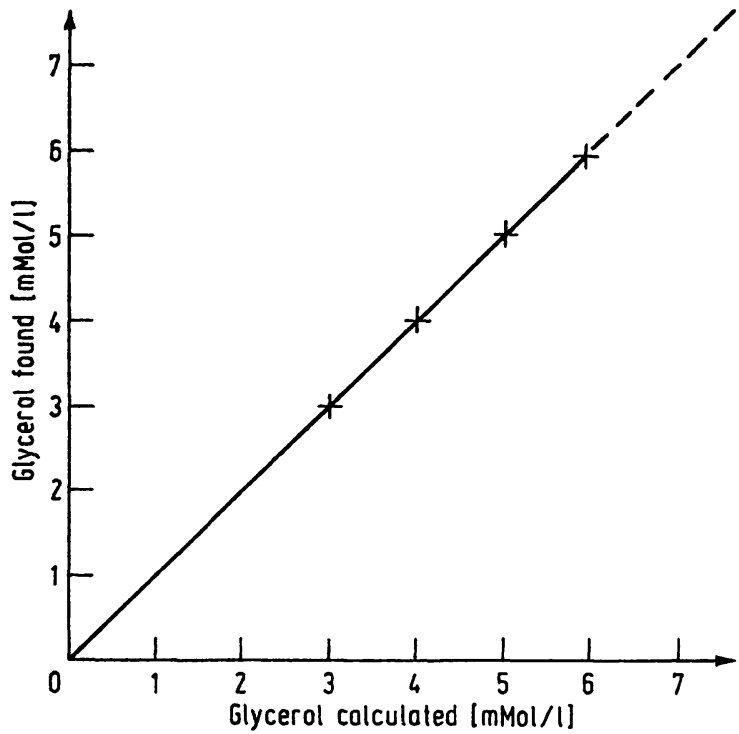

Fig. 6

Linearity of the triglyceride assay

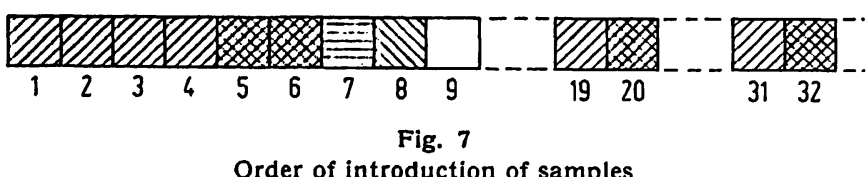

As shown by Figure 6 , the reaction continues to be linear up to 6.0 mMoles per litre when the concentration of $\mathrm{NADH}$ is $20 \mathrm{mg} / 120 \mathrm{ml}$.

The Figure 7 shows the order in which samples were introduced, in which adequate determination of quality was practicable.

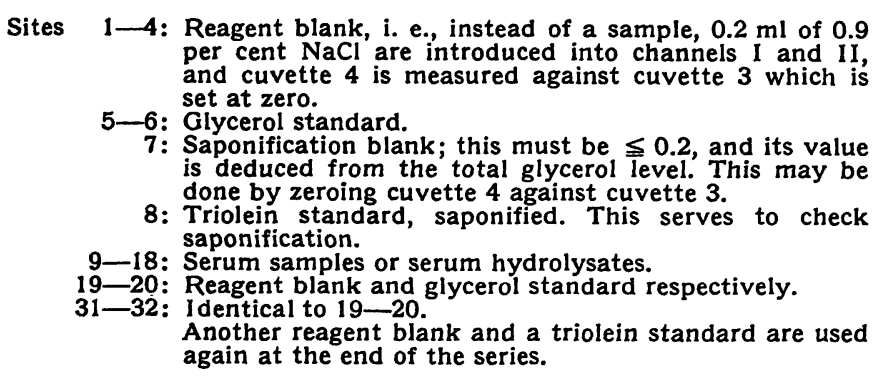

\section{Conclusion}

EgGSTEIN's enzyme triglyceride assay, adapted to the Perkin Elmer C-4 automatic analyzer by the present authors, was found to be highly reliable and rapid. With a few exceptions, it was found to be not necessary to estimate the free glycerol in addition to the total glycerol, which considerably reduces the length of this procedure.

\section{References}

1. KessLer, G. and H. LeDeren, Automation in analytical chemistry, p. 341-344, (1965). - 2. EgGSTEIN, M. and F. H. KreUTz, Klin. Wschr. 44, 262 (1966). - 3. SchMidt, F. H. and K. von DAHL, diese Z. 6, 156 (1968). - 4. EgGsteIN, M. and E.
KunLmanN, Methods of the Enzymatic Analysis, p. 1765 ed. by H. U. Bergmeyer, Verlag Chemie, Weinheim/Bergstraße (1970). 5. HoffmanN, R. G., J. Amer. Med. Ass. 185, 864 (1963). - 6. NeumanN, G. J., Clin. Chem., New York 14, 979 (1968).
Drs. R. J. M. van Oers Stichting Ignatius-Ziekenhuis Ignatiusstraat 11 Breda, The Netherlands 